\title{
Financing Analysis of Loan-Based Crowd Funding on Medium Small Micro Enterprises
}

\author{
Sati Ratna Dewanti*, Dinar Rika Septyaningtyas, Dandy Yuliansyah, Nindi Vaulia Puspita \\ Department of Economics \\ Kadiri University \\ Kediri, Indonesia \\ *satiratna08@gmail.com
}

\begin{abstract}
This study aims to determine the results of analysis Loan-Based Crowd funding on MSMEs in several countries on helping MSMEs obtain capital loans without a series of difficulties in administration and regulations. So, it can be used as a consideration for the government in making policies that can be applied in Indonesia. In this study, references from journal articles analyze to solve the problem. In this study, using references from journal articles analyzed to solve the problem. This research shows that loan-based crowd funding can be of positive value for business actors with the ease of making loans to maintain and develop the business.
\end{abstract}

Keywords—fintech, Loan-Based Crowdfunding, MSMEs

\section{INTRODUCTION}

In the era of the development of digital services, especially in the financial sector regarding fintech can increase the accessibility and availability of resources in the service system [1]. ZOPA is a Platform first loan-based crowd funding which was first introduced in 2005 in the UK, platform it provides loans to borrowers on an online basis on line [2]. Developmental improvement fintech is a continuous process that has an impact on high innovation in the field of financing [3]. One of the services offered by fintech is loan-based crowd funding or what is often known as loan-based crowd funding, peer-to peer-lending is one of a kind crowd funding the most popular, where platform the internet collects small amounts of funds from individuals in a group to collectively provide larger loans [4], besides platform lenders offer capital to borrowers using technology machine learning And algorithms for accessing the authenticity of the borrower [5].

The success of economic growth and development in Indonesia can be seen from the increasing development that is taking place in Indonesia. One of the sectors that plays an important role in the growth and development of the economy is the MSME sector [6]. Where, these activities are economic activities that can maintain their existence in various economic conditions. MSMEs have characteristics that can help them survive during a crisis. This happens because the smaller organizational size allows for flexible action when threats or opportunities come [7]. Even so, these MSME activities can be hampered due to business capital problems. In which, these MSME actors have difficulties in obtaining business capital credit from banks. A long series of regulatory and administrative processes from banks has triggered difficulties for MSMEs to get credit for their business capital [8]. The more rapid development of this technology encourages the actors involved in the sector to continue making new innovations so that their products and works can continue to exist. Besides, in the era pandemic which forces everyone to do everything according to health protocols also increasingly spurs MSME players to make new digital-based innovations. This can be seen from the increasing number of MSMEs implementing a payment based system online (e-payment), sales based on line and capital loans on line which offers convenience for borrowers. Unlike the traditional lending system, based lending on line. This is influenced by various factors that are not directly related to the credit profile of the borrower [9]. Fintech has a role in various things, namely not only limited to financing business capital but has also spread to various aspects such as digital payment services and also financial management [10]. But in fact there are still many MSME players who cannot take advantage of this digital transformation because they still lack understanding of the use of this technology, so they have difficulty obtaining capital loans that are usually obtained from banks with certain procedures and processes that are quite long, plus with this pandemic, it adds to a long line of difficulties for these MSMEs to obtain capital. As we all know, capital is a major obstacle for MSMEs. With these various problems, Loan-Based Crowd funding to MSMEs in several countries in helping MSMEs to get capital loans easily.

\section{RESEARCH METHODS}

Research conducted using literature review. In this study discusses the analysis of financing Loan-Based Crowd funding. The method used in the preparation of this study is to analyse the literature sourced from SINTA and SCOPUS indexed journal articles with the 2015-2020 publication period. 


\section{RESULTS AND DISCUSSION}

From several research results regarding the effects of development fintech especially in financing services or what is known as loan-based crowd funding among others are:

Research in China shows that this digital-based financing service is a type of service in the economic sector that can be used by MSMEs to obtain funds in developing their business. In general, MSMEs face difficulties and lack of funds in the process development [11]. In order to support the business development of an MSME in China, the government issued a policy to provide loans [12].

By providing adequate supporting facilities for MSMEs, it can be useful to increase access to finance, funding programs and financial schemes, with this it can help MSMEs to develop further [13]. Systematics in financial loans to MSMEs through loan-based crowd funding, platform provide financial loan services without the need for intermediaries so that loan funds can be distributed easily and quickly [14].

The analysis of the case studies in Thailand shows that there needs to be more learning and experience for developing countries to implement alternative services for digital-based financial sources, namely loan-based crowd funding for all MSMEs in a country. The role of government is really needed because it is running crowd funding loan based systems This will be very helpful for MSME players, so that economic growth in a country will increase [15].

Other research states that fintech can provide positive values for business actors, of course with various phenomena and resistance that can arise before or after implementing this technology. Fintech giving positive turmoil but besides that it also gives negative turmoil which this is natural to happen because MSME players are still unfamiliar with being able to accept technological changes in this financing sector [16]. For this reason, it is necessary to handle and calculate carefully when applying a technology in society.

The other study shows that fintech (loan-based crowd funding) has a significant influence on MSMEs. The existence loan-based crowd funding can help MSMEs in getting additional capital easily to maintain and improve their business, stated that $50.2 \%$ of MSMEs stated that access to new customers in Indonesia was greatly helped by the presence of digital technology, while access to new markets abroad was $33.7 \%$ [17]. For that we need support from the government such as strengthening security on line and coordinating comprehensively with various related parties, encouraging transaction payments non-cash (e-payment), as well as the UMKM web portal. Regulation of loan-based crowd funding could connecting investors crowd funding with entrepreneurs through transparency and transactions are fast and almost hassle-free in documentation [18]. Loan-based crowd funding is a digital service in the new financial sector, the service provider platform connects borrowers and lenders, so that loanbased crowd funding This is a threat to traditional banks because of the convenience and advantages it offers [19].
The other research in China found that the development of digital-based financing can support the improvement of an MSME. This is driven by the existence of diverse local cultures in China, which can show social heterogeneity, namely geographic location, language and social beliefs that can affect the level of sensitivity of local communities to existence. loanbased crowd funding [20]. The other study states that the choice of words in conveying a positive message regarding the results of funding loan-based crowd funding and increasing the positive impact of credit ratings on funding returns [21]. Karsen et al. in their research stated that the existence of a mobile payment system in the form of loan-based crowd funding plays an important role in electronic and cellular trading activities in Indonesia. The study in Bangladesh stated that MSMEs that do not have collateral and their assets are less likely to be rejected by the bank [22]. In South Africa, many banks have decided to revoke the policy of providing loans to MSMEs that are experiencing a business crisis and losses, on the other hand, on the other hand, the decision to provide credit for business capital is very necessary for MSMEs in developing their businesses. The development and success of these MSMEs can affect the economy in real terms [23].

Research in China shows that the level of social trust has a positive effect on access to loans from banks. Companies with a good level of social trust and political connections will get capital loans easily, while companies with a low level of social trust will tend to have difficulty obtaining capital loans from banks [24]. The research in China show that fintech can effectively provide credit to MSMEs [25]. Fintech also has a significant effect on increasing credit for MSMEs compared to banks. The study states that several companies Fintech in Turkey developing innovative products and services capable of providing high value to consumers and businesses [26]. The development of fintech services is increasingly evident from their ability to take decision. Another study in Turkey found that high GDP growth rates and intense competition between banks can increase the lending by banks to MSMEs. This cannot be separated from the efforts of the Turkish government, namely by reducing the rate of inflation and domestic borrowing, so that MSMEs can develop their businesses with capital loans provided by banks [27]. This research is in line with research conducted in Egypt, the Egyptian government provides various facilities, namely increasing MSME financing sources to encourage the growth of MSMEs in Egypt. Increased use of the internet is not significant in affecting the growth of MSMEs in the country under current social and economic conditions [28]. The other research states that the provision of loans by banks to MSMEs has a positive effect on the level of activity and economic growth in the country, this is because the provision of loans can reduce unemployment and crime rates in Nigeria [29]. Research found that there is a positive relationship between the provision of guarantees, low credit scores and default [30]. This shows that the provision of credit by banks is in line with the guarantees that can be provided by MSMEs to banks, resulting in difficulties for MSMEs to repay loans due to the imposition of too heavy loan costs. Factors that affect access to 
bank loans are the length of the company's relationship with the bank and the impression the bank gets from visits to the location. In addition, credit commitments and financial data can affect lending from banks. This is what makes MSMEs obtaining loan funds from banks takes a long time [31]. In applying for loans, borrowers from countries with higher levels of social capital are less likely to be rejected this is because the possibility of default is lower and the borrowing costs are low [32]. In addition, loans provided to borrowers in states with a higher level of social capital result in higher rates of return after controlling. The results show that microfinance loans play a positive role in developing a business. However, there are several factors that limit MSMEs access in applying for credit. These factors are a complicated process, business plan bad, as well as high credit costs. For lenders, access inside information loan-based crowd funding can help them to reduce misinformation, so that it can help them make decisions on a loan application [33]. MSMEs are a major factor in economic development. It can be seen at this time that in the debt crisis and the corona virus crisis, MSMEs are very vulnerable to an economic downturn. So that various supporting devices are needed [34]. The problems currently faced in the banking sector can increase borrowing costs, reduce credit availability and the productivity of MSMEs [35]. Loan-based crowd funding is thought to represent one of the newest forms of consumer and small business finance working towards financial inclusion [36]. Credit loans, banks choose MSMEs by relying on the company's credibility, economic strength and the company's ability to pay. However, credit generally has transaction characteristics lending because oriented to relationship lending [37]. It is recognized that SMEs are a major contributor to global employment and GDP. Likewise, the dependence of SMEs on financial banks to maintain financial and operational sustainability is also accepted globally. In 2008, the South African Companies Act was amended to overturn statutory auditing requirements for eligible entities, with the aim of reducing the administrative burden on SMEs and increasing their potential for sustainability. As this strategy sounds possible, a gray area emerges where banks may still demand audited financial reports [38]. MSMEs are the backbone of China's economy, but they still face challenges in accessing bank credit. So that MSMEs depend on various alternative sources, including informal finance, crowd funding loan-based platforms and registered non-banking financial institutions (NBFI) [39]. The joint liability loans in loan-based crowd funding more likely to default than an individual type loan. Loans with joint obligations can work not only in the offline market, but in loans loan-based crowd funding indicates that the type of loan may reflect potential loan risk. The difference in the assessment of credit risk, where customers who make loans at banks have a lower risk than borrowers who make loans at crowd funding loan-based platforms which has a high risk. However, Borrowers who have been rejected by the bank can be accepted and given a loan by crowd funding loan-based platforms, this causes the risk to be high [40].

\section{CONCLUSION}

Based on the results of the analysis of Loan-based crowd funding can help MSMEs by providing financing using LoanBased Crowd funding Regarding MSMEs in several countries, it can be concluded that:

- Access to new customers is greatly helped by digital technology

- convenience in making loans to maintain and develop businesses

- Loans through banks have a lower risk of default compared to Loan-based crowd funding Fintech can provide positive values for business actors

- The choice of words in conveying a positive message regarding the funding results loan-based crowd funding can increase the positive impact of credit ratings on funding returns

- Microfinance loans play a positive role in developing a business. Providing a significant impact on MSMEs

- Fintech can effectively provide credit to MSMEs

\section{ACKNOWLEDGMENT}

Thank you to SIMBELMAWA who have given confidence to implement PKM-PSH sourced from the PKM 5 Field 2020 Grant funding. Thank you for all the support that has been given by the Kadiri University Academic Community in the form of moral support and supporting facilities to complete this research. Thanks to the supervisor for all the support given in completing this research.

\section{REFERENCES}

[1] C.F. Breidbach, B.W. Keating, S.B. Qut, S.T. Manajemen, S.A. Bisnis, and I. Sains, "Fintech: arah penelitian untuk mengeksplorasi transformasi digital sistem layanan keuangan," vol. 30, no. 20184010201680, 2020.

[2] Y. Zhang, H. Li, M. Hai, J. Li, and A. Li, "Determinants of loan funded successful in online P2P Lending," Procedia Comput. Sci., vol. 122, pp. 896-901, 2017

[3] P. Schueffel, "Taming the Beast: A Scientific Definition of Fintech," J. Innov. Manag., vol. 4, no. 4, pp. 32-54, 2017.

[4] R. Lenz, "Peer-to-Peer Lending : Opportunities and Risks," Eur. J. Risk Reg., vol. 7, pp. 688-701, 2016.

[5] E.Z. Milian, M.M. Spinola, and M.M.de. Carvalho, "Fintechs: A literature review and research agenda," Electron. Commer. Res. Appl., vol. 34, no. January, 2019.

[6] M. Rizal, E. Mulina, and N. Kostini, "AdBispreneur: Jurnal Pemikiran dan Penelitian Administrasi Bisnis dan Kewirausahaan," J. Pemikir. dan Penelit. Adm. Bisnis dan Kewirausahaan, vol. 3, no. 2, pp. 89-100, 2018.

[7] F. Eggers, "Masters of disasters? Challenges and opportunities for SMEs in times of crisis," J. Bus. Res., vol. 116, no. May, pp. 199-208, 2020. 
[8] T. Ardiansyah, "Model Financial Dan Teknologi (Fintech) Membantu Permasalahan Modal Wirausaha UMKM Di Indonesia,” Maj. Ilm. Bijak, vol. 16, no. 2, pp. 158-166, 2019.

[9] M. Cummins, C. Mac an Bhaird, P. Rosati, and T. Lynn, "Institutional investment in online business lending markets," Int. Rev. Financ. Anal., vol. 71, no. February, p. 101542, 2020

[10] E.N. Sugiarti, "E-JRA Vol. 08 No. 04 Agustus 2019 Fakultas Ekonom dan Bisnis Universitas Islam Malang," vol. 08, no. 10, pp. 116-130, 2019.

[11] T. Yu and W. Shen, "Funds sharing regulation in the context of the sharing economy: Understanding the logic of China's P2P lending regulation," Comput. Law Secur. Rev., vol. 35, no. 1, pp. 42-58, 2019.

[12] L. Xia, "Research on the impact of financial ecological environment on SME financing," Ekoloji, vol. 28, no. 107, pp. 1633-1640, 2019.

[13] H.M. Osano and H. Languitone, "Factors influencing access to finance by SMEs in Mozambique: case of SMEs in Maputo central business district," J. Innov. Entrep., vol. 5, no. 1, 2015.

[14] S. (Fone) Pengnate and F.J. Riggins, "The role of emotion in P2P microfinance funding: A sentiment analysis approach," Int. J. Inf. Manage., vol. 54, no. August 2019, 2020.

[15] J. Wonglimpiyarat, "Challenges and dynamics of FinTech crowd funding: An innovation system approach," J. High Technol. Manag. Res., vol. 29, no. 1, pp. 98-108, 2018.

[16] D. Luckandi, "Analisis Transaksi Pembayaran Menggunakan Fintech Pada UMKM di Indonesia : Pendekatan Adaptive Structuration Theory," Skripsi Fak. Teknol. Ind. Univ. Islam Indones., pp. 1-98, 2018.

[17] B. Tedjasuksmana and P.J.F. Nagel, "Bank Koperasi Dan Financial Technology: Lembaga Dan Inovasi Pemberdayaan Operasional Keuangan Umkm Memasuki 2025 Pasca ACFTA (ASEAN China Free Trade Area)," Prosiding Seminar Nasional Sains dan Teknologi Terapan, vol. 1, no. 1, pp. 157-162, 2019.

[18] A.A. Sa'ad, K. Ahmad, and A.O.H. Saleh, "P2p islamic fintech investment innovation. A proposal of mushĀrakah smart contract model for smes financing and social development," Al-Shajarah, vol. 2019, pp. 169-184, 2019.

[19] M. Polena and T. Regner, "Determinants of borrowers' default in P2P lending under consideration of the loan risk class," Games, vol. 9, no. 4, pp. $1-17,2018$

[20] J. Jiang, Y.J. Liu, and R. Lu, "Social heterogeneity and local bias in peer-to-peer lending - evidence from China," J. Comp. Econ., vol. 48 , no. 2, pp. 302-324, 2020.

[21] J. Huang, V. Sena, J. Li, and S. Ozdemir, "Message framing in P2P lending relationships,” J. Bus. Res., no. xxxx, 2020.

[22] A. Rahman, J. Belas, Z. Rosza, and T. Kliestik, "Does bank ownership affect relationship lending: A developing country perspective," J. Int. Stud., vol. 10, no. 1, pp. 277-288, 2017.

[23] F. Akinsola and S. Ikhide, "Bank Lending to Small and Medium Scale Enterprises (SMES) and Business Cycle in South Africa after the Global Financial Crisis,” J. Dev. Areas, vol. 53, no. 1, pp. 79-94, 2019.
[24] D. Chen, X. Liu, and C. Wang, "Social Trust and Bank Loan Financing: Evidence from China," Abacus, vol. 52, no. 3, pp. 374-403, 2016.

[25] T. Sheng, "The effect of fintech on banks' credit provision to SMEs: Evidence from China," Financ. Res. Lett., vol. 39, no. April, p. 101558 2020

[26] K. Degerli, "Regulatory Challenges and Solutions for Fintech in Turkey,” Procedia Comput. Sci., vol. 158, pp. 929-937, 2019.

[27] H. Jenkins and M. Hossain, "Analisis Kondisi Makroekonomi yang Diperlukan untuk Pemberian Pinjaman UKM: Bukti dari Turki dan Negara Pasar Berkembang Lainnya,” vol. 64, no. 560, pp. 77-93, 2017.

[28] N. Ahmed and S.H. Kim, "Developing Small and Medium-Sized Enterprises in Islamic Developing Countries: Exploring the Influential Factors for Egypt," Asian Econ. Financ. Rev., vol. 10, no. 6, pp. 670679, 2020.

[29] U.A. Ibrahim and I.M. Ndidi, "Effect of bank lending on the growth of selected SMEs in Nigeria," Int. J. Res. Bus. Soc. Sci. (2147-4478), vol. 9, no. 4, pp. 237-243, 2020.

[30] F.D. Duarte, A.P.M. Gama, and M.A. Gulamhussen, "Defaults in bank loans to SMEs during the financial crisis," Small Bus. Econ., vol. 51, no. 3, pp. 591-608, 2018.

[31] A.I. Erdogan, "Factors affecting SME access to bank financing: an interview study with Turkish bankers," Small Enterp. Res., vol. 25, no. 1, pp. 23-35, 2018.

[32] H. Lu, B. Wang, H. Wang, and T. Zhao, "Does social capital matter for peer-to-peer-lending? Empirical evidence,” Pacific Basin Financ. J., vol. 61, no. February, p. 101338, 2020.

[33] Z. Wang, C. Jiang, H. Zhao, and Y. Ding, "Mining Semantic Sof Factors for Credit Risk Evaluation in Peer-to-Peer Lending," J. Manag. Inf. Syst., vol. 37, no. 1, pp. 282-308, 2020.

[34] Y. Polishchuk, A. Kornyliuk, I. Lopashchuk, and A. Pinchuk, "SMEs debt financing in the EU: on the eve of the coronacrisis," Banks Bank Syst., vol. 15, no. 3, pp. 81-94, 2020.

[35] H. Ramcharran, "Bank lending to small business in India: Analyzing productivity and efficiency," Q. Rev. Econ. Financ., vol. 65, pp. 16-24, 2017

[36] C. Rogers and C. Clarke, "Mainstreaming social finance: The regulation of the peer-to-peer lending marketplace in the United Kingdom," Br. J. Polit. Int. Relations, vol. 18, no. 4, pp. 930-945, 2016.

[37] Z. lin Song and X. mei Zhang, "Lending technology and credit risk under different types of loans to SMEs: Evidence from China," Int. Rev. Econ. Financ., vol. 57, no. 2017, pp. 43-69, 2018.

[38] F. Coetzee and P.W. Buys, "The impact of the independent review on SME access to bank finance: The case of South Africa," Banks Bank Syst., vol. 12, no. 1, pp. 135-142, 2017.

[39] K.S. Tsai, "When Shadow Banking Can Be Productive: Financing Smal and Medium Enterprises in China," J. Dev. Stud., vol. 53, no. 12, pp. 2005-2028, 2017.

[40] T. Jørgensen, "Peer-to-Peer Lending - A New Digital Intermediary, New Legal Challenges,” Nord. J. Commer. Law, no. 1, pp. 30-30, 2018. 